\title{
Different reactivity of monoclonal antibodies against common acute lymphoblastic leukaemia antigen (CD10)
}

\author{
STELLA HARALAMBIDOU, JUNIA V MELO, D CATOVSKY \\ From the Medical Research Council Leukaemia Unit, Royal Postgraduate Medical School, London
}

SUMMARY The reactivity of five monoclonal antibodies J5, OKB-cALLA, Nu-N1, Nu-N2 and VIL-A1 against the common acute lymphoblastic leukaemia (common-ALL) antigen (glycoprotein 100, CD10); was investigated by indirect immunofluorescence in cell suspensions, and by immunoperoxidase in cytocentrifuge slides of ALL, chronic B cell lymphoproliferative disorders, and plasma cell dyscrasias. The five monoclonal antibodies gave similar positive results with both techniques only in samples of ALL. J5 was positive in variable degrees by immunofluorescence in the majority of B cell disorders examined but this was not confirmed by immunoperoxidase. OKBcALLA reacted in a similar way to $\mathrm{J} 5$ in both techniques, although with a lower percentage of cells by immunofluorescence. $\mathrm{Nu}-\mathrm{N} 1, \mathrm{Nu}-\mathrm{N} 2$, and VIL-A1 were mainly negative when tested by both immunofluorescence and immunoperoxidase in B cell disorders other than ALL and therefore seemed to be more specific for the diagnosis of common-ALL.

The acute lymphoblastic leukaemia (ALL) antigen is a surface glycoprotein (gp) of 100000 daltons ${ }^{1-4}$ and is an important marker for the identification of common-ALL in children and adults. It was first detected by an extensively absorbed rabbit antisera ${ }^{2}$ and later by a murine monoclonal antibody $\mathrm{J} 5^{3}$ that has been widely used for the diagnosis of leukaemia. In addition to common-ALL, J5 has also been found to react with various forms of $B$ and $T$ cell malignancies, ${ }^{56}$ and $\mathrm{J} 5$ positivity has become a diagnostic marker of follicular lymphoma when used in tissue sections. ${ }^{7}$ During routine immunophenotyping of leukaemias and lymphomas we noticed that $\mathrm{J} 5$ was unexpectedly reactive with cells of chronic B cell leukaemias. We therefore carried out a comparative study of the pattern of reactivity of $\mathrm{J} 5$ and four other monoclonal antibodies against gp 100, using both immunofluorescence and immunoperoxidase techniques.

\section{Material and methods}

Fresh cells were obtained from peripheral blood or bone marrow, or both, as well as from spleen and lymph nodes from patients with the following diag-

Accepted for publication 25 November 1986 noses: acute lymphoblastic leukaemia (ALL) $(n=6)$, chronic lymphocytic leukaemia (CLL) $(\mathrm{n}=12)$, B cell prolymphocytic leukaemia (B-PLL) $(n=3)$, hairy cell leukaemia $(\mathrm{HCL})(\mathrm{n}=4)$, non-Hodgkin's lymphoma in leukaemic phase $(n=15)$, which included various disorders such as follicular lymphoma, nonHodgkin's lymphoma with lymphoplasmacytic differentiation, and plasma cell disorders $(n=4)$; the latter included myelomatosis and plasma cell leukaemia. The diseases were classified as of B lineage by conventional techniques, including evidence of monoclonal immunoglobulin on the cell surface or cytoplasm and reactivity with the anti-B cell monoclonal antibody anti-B1 (CD20) and anti-B4(CD19). The following monoclonal antibodies against gp 100 (CD10) were used: J5, IgG2a class (Coulter-Clone); OKB-cALLA, IgG3 (Ortho-mune); Nu-N1, IgG1, and Nu-N2, IgG2b (Nishirei Corporation, Japan); and VIL-A 1, ${ }^{9}$ IgM $\kappa$ (gift from Professor W Knapp, Institute of Immunology, University of Vienna).

The mononuclear cells were isolated by density centrifugation on Lymphoprep (Nyegaard) and washed three times in Hanks's balanced salt solution (Gibco). Cytospin slides were prepared by centrifugation of $100 \mu \mathrm{l}$ of a cell suspension $\left(1 \times 10^{6} \mathrm{cell} / \mathrm{ml}\right)$ for 5 minutes at $400 \mathrm{rpm}$ in a Shandon cytocentrifuge. The reactivity with monoclonal antibodies was assessed 
by immunofluorescence and immunoperoxidase techniques as follows.

\section{IMMUNOFLUORESCENCE ON CELL SUSPENSION} Cell suspension $(50 \mu \mathrm{l})$ at a concentration of $2 \times 10^{6} / \mathrm{ml}$ was incubated for 30 minutes at $4^{\circ} \mathrm{C}$ with the relevant monoclonal antibody at its optimal dilution ( $1 / 20$ for J5, OKB-cALLA, Nu-N1, and Nu-N2, and $1 / 100$ for VIL-A1). After three washes with phosphate buffered saline (PBS) containing $0 \cdot 2 \%$ sodium azide (Sigma) and $0.2 \%$ bovine serum albumin the cells were incubated for 30 minutes at $4^{\circ} \mathrm{C}$ with $50 \mu$ l of a fluorescein isothiocyanate (FITC)-conjugated $F(a b) 2$ fragment of goat antimouse IgG (Cappel), cross reactive with mouse IgM. After three washes in buffer the cells were resuspended in one drop of PBS and Glycerol 50:50, mounted on slides, and examined under a Zeiss immunofluorescence microscope.

\section{IMMUNOPEROXIDASE ON FIXED CELLS}

The cells on cytospin slides were fixed in acetone for 15 minutes at room temperature. After washing for 10 minutes in PBS the slides were incubated in $10 \% \mathrm{AB}$ serum in PBS for 20 minutes and after a second wash they were incubated with $20 \mu \mathrm{l}$ of monoclonal antibody for 30 minutes at room temperature. A peroxidase conjugated rabbit antimouse IgG (Dako Ltd) was used as the second layer, and as the third layer a peroxidase conjugated swine antirabbit IgG (Dako Ltd) was used. The peroxidase reaction was developed by incubation in a $0.6 \%$ solution of diaminobenzidine containing $0.01 \%$ of hydrogen peroxide. This was followed by counterstaining in haematoxylin and mounting in DPX. The slides were examined under a light microscope. For J5 a slight modification of the immunoperoxidase technique was used: the slides were fixed in acetone:methanol (50:50) for 90 seconds and $30-40 \mu$ lo the monoclonal antibody was applied to the cell area which was then immunoperoxidase technique, J5 was diluted $1 / 100$ in PBS; all the other monoclonal antibodies were used at the same dilution as for tests in suspension.

For controls of the immunofluorescence and immunoperoxidase reactions the first layer monoclonal antibody was omitted and replaced by nonimmune mouse ascites.

\section{Results}

All five monoclonal antibodies reacted similarly by immunoperoxidase and immunofluorescence with cells of the six cases of common-ALL (table). Only OKB-cALLA showed a slightly lower reactivity by immunoperoxidase, which was due to a lower percentage of positive cells in two cases (tested twice). In CLL and PLL J5 was reactive with one fifth of cells by immunofluorescence but this was not confirmed by the immunoperoxidase technique (table). OKBcALLA was positive in a lower percentage of cells by both methods, and Nu-N1, Nu-N2, and VIL-A1 were negative in these $B$ cell leukaemias. In HCL J5 was positive in the only case tested by immunofluorescence; the other monoclonal antibody reacted only with a minority of hairy cells by both techniques; $\mathrm{J} 5$ was negative in all the HCL cases when tested by immunoperoxidase.

In the group of patients with non-Hodgkin's lymphoma $(n=9)$, excluding cases with lymphoplasmacytic differentiation, J5 was positive in one third of cells by immunofluorescence and was negative by immunoperoxidase; OKB-cALLA was positive in one fifth of cells by the former and in a lower proportion by the latter method. The other three monoclonal antibodies detected a low percentage of positive cells by immunofluorescence and were unreactive by immunoperoxidase. In the only case with confirmed follicular lymphoma J5 was positive in $50 \%$ and $\mathrm{N} 1$ and $\mathrm{N} 2$ were negative. In the cases of

Table Summary of findings with anti-cALLA monoclonal antibodies*

\begin{tabular}{|c|c|c|c|c|c|c|c|c|c|c|}
\hline \multirow[b]{2}{*}{$\begin{array}{l}\text { Disease } \\
\text { (No of cases) }\end{array}$} & \multicolumn{2}{|l|}{$J 5$} & \multicolumn{2}{|l|}{$O K B-c A L L A$} & \multicolumn{2}{|l|}{$N u-N I$} & \multicolumn{2}{|l|}{$\mathrm{Nu}-\mathrm{N2}$} & \multicolumn{2}{|l|}{$V I L-A I$} \\
\hline & $\begin{array}{l}\text { Immuno- } \\
\text { fluorescence }\end{array}$ & $\begin{array}{l}\text { Immuno- } \\
\text { peroxidase }\end{array}$ & $\begin{array}{l}\text { Immuno- } \\
\text { fluorescence }\end{array}$ & $\begin{array}{l}\text { Immuno- } \\
\text { peroxidase }\end{array}$ & $\begin{array}{l}\text { Immuno- } \\
\text { fluorescence }\end{array}$ & $\begin{array}{l}\text { Immuno- } \\
\text { peroxidase }\end{array}$ & $\begin{array}{l}\text { Immuno- } \\
\text { fluorescence }\end{array}$ & $\begin{array}{l}\text { Immuno- } \\
\text { peroxidase }\end{array}$ & $\begin{array}{l}\text { Immuno- } \\
\text { fluorescence }\end{array}$ & $\begin{array}{l}\text { Immuno- } \\
\text { peroxidase }\end{array}$ \\
\hline $\begin{array}{l}\text { ALL (6) } \\
\text { CLL (12) } \\
\text { PLL (3) } \\
\text { HCL (4)† } \\
\text { NHL (9), }\end{array}$ & $\begin{array}{l}83(1) \\
21(12) \\
23(10) \\
48 \%\end{array}$ & $\begin{array}{l}82(4) \\
\text { Negative } \\
\text { Negative } \\
\text { Negative }\end{array}$ & $\begin{array}{l}80(12) \\
8(13) \\
13(4) \\
28\end{array}$ & $\begin{array}{c}54(36) \\
8(9) \\
4(3) \\
7(5)\end{array}$ & $\begin{array}{c}80(16) \\
1(1) \\
4(7) \\
9\end{array}$ & $\begin{array}{l}86(9) \\
\text { Negative } \\
\text { Negative } \\
\text { ND }\end{array}$ & $\begin{array}{l}81(15) \\
1(2) \\
2(3) \\
7\end{array}$ & $\begin{array}{l}79(15) \\
\text { Negative } \\
\text { Negative } \\
1(2)\end{array}$ & $\begin{array}{l}87 \\
\text { Negative } \\
1(1) \\
13 \%\end{array}$ & $\begin{array}{l}65(24) \\
\text { Negative } \\
\text { Negative } \\
3(6)\end{array}$ \\
\hline $\begin{array}{l}\text { (various) } \\
\text { NHL (6), } \\
\text { (lympho- }\end{array}$ & $33(12)$ & $1(2)$ & $22(4)$ & $7(8)$ & $5(5)$ & Negative & $4(3)$ & $1(2)$ & $7(11)$ & Negative \\
\hline $\begin{array}{l}\text { plasmocytic) } \\
\text { PCD (4) }\end{array}$ & $\begin{array}{l}16(2) \\
18(6)\end{array}$ & $\begin{array}{l}1(1) \\
2(3)\end{array}$ & $\begin{array}{l}12(8) \\
12(2)\end{array}$ & $\begin{array}{l}7(9) \\
5(7)\end{array}$ & $\begin{array}{l}2(3) \\
0\end{array}$ & $\begin{array}{l}\text { Negative } \\
\text { Negative }\end{array}$ & $\begin{array}{l}2(3) \\
2(3)\end{array}$ & $\begin{array}{l}\text { Negative } \\
\text { Negative }\end{array}$ & $\begin{array}{l}2 \\
4(5) \%\end{array}$ & $\begin{array}{l}\text { Negative } \\
\text { Negative }\end{array}$ \\
\hline
\end{tabular}

*Results expressed as mean \pm SD\% of positive cells; tonly one case tested by immunofluorescence, all the others tested by immunoperoxidase. 
non-Hodgkin's lymphoma with plasmacytic differentiation, which were mainly cases with splenomegaly and villus lymphocytes in the peripheral blood, J5 was positive in some cells by immunofluorescence alone. Again OKB-cALLA was positive in a lower proportion of cells by both techniques and the other reagents were mostly negative by both methods.

In the cases of PCD, two of myelomatosis (bone marrows) and two of plasma cell leukaemia, J5 was positive in plasma cells by immunofluorescence and reacted in one case with only $6 \%$ of cells by immunoperoxidase. OKB-cALLA was positive by both techniques in a lower percentage of cells and the other monoclonal antibodies were largely negative.

In summary, J5 was positive in a variable percentage of cells by immunofluorescence in most of the cases examined, but only in common-ALL was a similar degree of reactivity shown by immunoperoxidase. OKB-cALLA also reacted in most cases, although in a lower percentage of cells than $\mathrm{J} 5$, by both techniques. All the five monoclonal antibodies examined were strongly positive by both methods in commonALL; Nu-N1, Nu-N2, and VIL-A1 were mainly unreactive with cells of all the other B cell disorders by either method.

\section{Discussion}

Our study shows that all the five monoclonal antibodies tested against group 100 (CD10) gave similar results in common-ALL when tested either by immunofluorescence (on cell suspension) or by immunoperoxidase (on cells fixed on cytospin slides). A considerable difference was noted between the findings by the two methods in all the other cases. This difference was observed with all the reagents, in particular J5 and OKB-cALLA, although the OKBcALLA detected a lower percentage of cells than J5 by immunofluorescence. J5 was positive by this method in nearly all the B cell disorders examined but in most of the cases this was not confirmed either by immunoperoxidase or by the results given by the other anti-gp 100 monoclonal antibodies used. $\mathrm{Nu}-\mathrm{N} 1, \mathrm{Nu}-\mathrm{N} 2$, and VIL-A1 were not found in most of the lymphoproliferative diseases and thus it seemed that they were more restricted to the detection of the common-ALL antigen in lymphoblasts. We do not know why these monoclonal antibodies reacted in such a different way and why $\mathbf{J} 5$ gave the same results by both techniques in common-ALL lymphoblasts but not in the cells from other disorders.

In a separate study from this laboratory (unpublished observations) it was found that the optimal titre of $\mathrm{J} 5$ necessary to achieve the same results by the two methods was limited to a narrow range of dilutions; low dilutions $(1 / 5)$ could give false positive results and background staining by immunoperoxidase though high dilutions $(1 / 250)$ often yielded no reaction on fixed cells. Even if the only reliable results were those obtained with this group of monoclonal antibodies (CD10) by immunofluorescence, J5, and to a lower degree OKB-cALLA, were positive in most conditions tested, albeit not in a high proportion of cells. This observation may explain why others have reported conflicting results. A minority of cells in B-PLL were found to be positive in this study, but not by Greaves et $a l^{6}$ using a FACS analyser, while Berrebi et al ${ }^{10}$ found that most B-PLL were J5 positive; similar variations were reported in CLL. ${ }^{11}$ In the plasma cell disorders the positivity with $\mathrm{J} 5$ was reported to correspond to a subtype with a bad prognosis. ${ }^{12}$ In HCL the hairy cells were $\mathrm{J} 5$ positive in the only case tested by immunofluorescence; our previous experience in five other cases tested with $\mathrm{J} 5$ in this way showed that four were strongly positive (data not shown).

Our study suggests that $\mathrm{J} 5$, and to a lesser extent OKB-cALLA, react with common-ALL and that they were also positive in most $\mathrm{B}$ cell malignancies examined. In contrast, $\mathrm{Nu}-\mathrm{N} 1, \mathrm{Nu}-\mathrm{N} 2$, and VIL-A1 seem to be restricted to common-ALL, even though they did react in some cases of B cell leukaemias but with a lower percentage of cells than $\mathrm{J} 5$. It may be that both $\mathrm{J} 5$ and OKB-cALLA have a greater avidity for the gp 100 antigen and are thus able to detect smaller B cell populations other than lymphoblasts which express this antigen at low densities. Readings of positive samples of common-ALL by means of flow cytometry with a FACS analyser showed that the intensity of fluorescence was greater with $\mathrm{J} 5$ than with the other anti-cALLA monoclonal antibodies. Alternatively, the differences in reactivity of the various antibodies may indicate that the 100000 daltons glycoprotein has two or more antigenic determinants which are selectively recognised by each monoclonal antibody. It is thus possible that in common ALLlymphoblasts both (or more) epitopes of the glycoprotein are expressed, but in cells from other B cell leukaemias only the epitope recognised by $\mathrm{J} 5$ is conserved and the other (or others) are modified. Changes which could lead to differences in some epitopes include modifications in transcription and translation of the gene, post-translational modifications of the polypeptide, and glycosylation differences. If there is a family of group $\mathbf{1 0 0}$ molecules their value as markers of differentiation may be considerable, and studies of the genetic mechanisms entailed in the control of their expression seem warranted.

The differences reported here, between $\mathrm{J} 5$ (and OKB-cALLA) and other anti-group 100 monoclonal antibodies of the CD10 group in diseases other than 
common-ALL, have not been described before to our knowledge. They emphasise the importance of reexamining more critically the biological and clinical importance of the use of these reagents for the diagnosis of B cell disorders in general. Attention should also be paid to the differences observed in reactivity with the same reagent when tested by immunofluorescence and immunoperoxidase, although the findings did not affect results in common-ALL where all reagents tested both by immunofluorescence or immunoperoxidase performed equally well.

We thank Professor W Knapp for the gift of VIL-Al. Dr JV Melo was supported by a grant from CAPES, Brasil.

\section{References}

1 Newman RA, Sutherland R, Greaves MF. The biochemical characterization of a cell surface antigen associated with acute lymphoblastic leukemia and lymphocyte precursors. J Immunol 1981;126:2024-30.

2 Greaves MF, Brown G, Rapson NT, Lister TA. Antisera to acute lymphoblastic leukemia cells. Clin Immunol Immunopathol 1975;4:67-84.

3 Ritz J, Pesando JM, Notis-McConarty J, Lazarus H, Schlossman SF. A monoclonal antibody to human acute lymphoblastic leukeamia antigen. Nature 1980;283:583-5.

4 Greaves M, Verbi W, Vogler L, et al. Antigenic and enzymatic phenotypes of the pre-B subclass of acute lymphoblastic leukaemia. Leuk Res 1979;3:353-62.

5 Ritz J, Nadler LM, Bhan AK, Notis-McConarty J, Pesando JM, Schlossman SF. Expression of common acute lymphoblastic leukemia antigen (CALLA) by lymphomas of B-cell and T-cell lineage. Blood 1981;58:648-52.

6 Greaves MF, Hariri G, Newman RA, Sutherland DR, Ritter MA, Ritz J. Selective expression of the common acute lymphoblastic leukemia (gp 100) antigen on immature lymphoid cells and their malignant counterparts. Blood 1983;61:628-39.

7 Stein H, Gerdes J, Mason DY. The normal and malignant germinal centre. Clin Haematol 1982;11:531-59.

8 Anderson KC, Bates MP, Slaughenhoupt BL, Pinkus GS, Schlossman SF, Nadler LM. Expression of human B cellassociated antigens in leukemias and lymphomas: a model of human B cell differentiation. Blood 1984;63:1424-33.

9 Knapp W, Majdic O, Bettelheim P, Liszka K. VIL-A1, a monoclonal antibody reactive with common acute lymphatic leukemia cells. Leuk Res 1982;6:137-47.

10 Berrebi A, Talmor M, Galili N. J5 antibody and prolymphocytic leukemia. Blood 1983;62:1150-1.

11 Ligler FS, Schlam ML, Curley R, Brodsky I, Benzel JE. Monocyte markers and the common acute lymphoblastic leukemia on chronic lymphocytic leukemia cells. Am J Hematol 1983; 15:335-42.

12 Durie BGM, Grogan TM. CALLA-positive myeloma: an aggressive subtype with poor survival. Blood 1985;66:229-32.

Requests for reprints to: Dr D Catovsky, MRC Leukaemia Unit, Royal Postgraduate Medical School, London, W12 0HS, England. 